\title{
Absenteeism, labour turnover and management style
}

\author{
P. G. Human
}

Labour turnover and absenteeism rates are relatively easily measurable forms of behaviour. This article investigates the validity of these rates as indicators of organizational effectiveness. It is argued that management style and motivational strategies are related to absenteeism and labour turnover. Absenteeism and labour turnover are viewed as examples of deviant industrial behaviour and consequently as reflections of employee dissatisfaction with management. The implications of the incidence of and variations in these two phenomena are discussed together with their relevance to successful management, and their practical applicability as tools to aid the employer.

$$
\text { S. Atr. J. Bus. Mgmt 1979, 10: 53-56 }
$$

Arbeidsomset- en werksafwesigheidsyfers is redelik maklik meetbare verskynsels en word jaarliks in meeste bedrytsorganisasies bepaal. Hierdie artikel ondersoek die geldigheid van hierdie syfers as indikatore van organisasie-effektiwiteit. Die argument is dat bestuurstyl en motiveringstrategie aan die een kant, verband hou met werksałwesigheid en arbeidsomset aan die ander kant Werksafwesigheid en arbeidsomset word beskryt as voorbeelde van afwykende industriële gedrag en daarom as wyses waarop werknemers hul ontevredenheid ten opsigte van die werkgewers uitdruk. Die implikasies van die voorkoms en variasies van hierdie twee verskynsels word bespreek, asook hulle praktiese toepasbaarheid as hulpmiddels vir die werkgewer, en hulle verband met suksesvolle bestuur.

S.-Afr. Tydskr. Bedryisl. 1979, 10: 53-56
The minimum definition of an organization is that it is a social unit capable of more or less continuous and coordinated policies and actions. An organization consists of a plural number of organisms who have a collective perception of their unity and who have the ability to act in a unitary manner toward the environment. This implies specified goals, differentiation of tasks and functions, and a subgroup which has the monopoly of power to control and structure the organization in order to realize specific goals. An organization is primarily typified by the nature of its goals. An organization is not a social unit haphazardly wandering around in the greater social system; it forms part of the greater system. Moreover, it is also a member of a plural number of organisms which act in a unitary manner with other organisms in order to realize a common goal. Consequently, society can be defined as a compilation of different social units, each with a specific task and each working towards the realization of the primary goal of the society, that is the building of a sustainable society. Each unit again strives toward sustainability. Sustainability is a function of the degree to which the unit fits into the web of relationships in which it is found, and thus, the degree to which it fulfils its goals.

An organization is a living and growing entity which continuously changes its elements and direction of flow in order to adapt to, and fit into, the web of relationships which also grow and change. Growth and change again are the product of the interaction between man and his environment. Man both creates, and is created by, his environment. This process produces new aspirations and needs and therefore creates the need for new organizations to fulfil such aspirations and needs.

The business organization's primary goal is to produce goods and/or services. The process of production is the continuous importing of energy inputs from the environment and the transformation of this energy into output energy. ${ }^{2}$ The energy referred to here can take any form, inter alia, fuel, food, raw materials, human, animal or mechanical activity, human thought and sunlight. The energy flow process forms certain patterns which are determined by the formal structure of the organization.

In broader context the social sciences are interested in the behaviour of people as elements of energy found within the 
The following hypotheses were formulated in terms of

structure of organizations. This implies formally structured roles and tasks for each individual and a formal system of relationships; also called the objective system of relationships. But, apart from the objective system of relationships, $\therefore$. . a system of relationships (is) latent (hidden) in the "objective view" of reality which structure presents'. ${ }^{2}$ This 'hidden' system of relationships is called the informal system of relationships. The system of relationships between the people in the organization thus, consists of both formal and informal systems of relationships. The roles and the tasks of an individual in an organization are consequently dualistic. The individual's role in the formal system of relationships is primarily instrumental or economic, while his role in the informal system of relationships is primarily expressive or socio-emotional. Instrumental activities refer to the energy flow process (the process which produces and therefore realizes the goals of the organization) while expressive activities refer to the socio-emotional processes present in the interaction between individuals as members of the informal system of relationships. ${ }^{3}$

The subgroup which has a monopoly of power (managers) manipulates and controls the energy input-output process in order to realize organizational goals. Two modes of manipulation or control of the people in the organization are found, namely situational sanctions and intentional sanctions. "The term "sanction", in its widest sense, means any measure taken in support of a social order regulating human behaviour'. ${ }^{4}$ If a person, the ego, intends regulating the behaviour of another person, the alter, the ego may attempt to change the actual situation in which the alter is placed (situational sanctions) or he might attempt to change the alter's intentions (intentional sanctions). 5

The goals of the formal system of relationships, as well as the modes of achieving these goals, may clash with the goals and modes of the informal system of relationships, in view of the different needs these two systems fulfil. These opposed interests and needs are 'real' in the sense that they arise from the nature of the organization in which these two systems are enmeshed. Deviant industrial behaviour might display itself in different forms and intensities as a result of this conflict. The '. . . banding together (of workers) informally in order to protect themselves against practices which they interpreted as a menace to their welfare ${ }^{\prime 6}$ might lead to the manifestation of certain forms of behaviour, such as absenteeism, labour turnover, low productivity, late arrival at work, vandalism, accidents, and strikes.

This article proposes that these easily measured forms of behaviour are manifestations of the employee's feelings of well-being or lack thereof, and can thus be used as indicators of organizational effectiveness. These indicators refer to the degree of fit between the formal and informal systems of relationships and therefore to the satisfaction, dissatisfaction, content or discontent experienced by the worker. However, the nature of the modes of sanctions applied and the level of motivation experienced by the 'employee' will also have a bearing on his or her feeling of well-being.

The author attempts to relate two kinds of indicators of worker well-being and, by implication, organizational effectiveness, namely indicators of deviant industrial behaviour (absenteeism and labour turnover) on the one hand, and indicators of worker attitude towards management (the individual's perception of sanctions used by management, and his level of motivation) on the other. this perspective:

- The patterns and variations in the incidence of absenteeism and labour turnover will coincide.

- People-oriented management styles, that is emphasis on intentional sanctions rather than on situational sanctions, will result in low rates of deviant industrial behaviour, and conversely, production-oriented management styles will result in high rates of deviant industrial behaviour.

- The level of motivation and the incidence of deviant industrial behaviour are related. ${ }^{7, p .} 27$

\section{Research Design}

A comparative study of four industrial organizations was undertaken. These four organizations do not differ much in terms of kind of industry, geographical location, formal policy, size of organization, age and sex of workers, educational status of workers, length of service, wage structure, facilities offered to workers and formal structure of authority; ${ }^{7,},{ }^{28}$ all of these factors are known to influence absenteeism and labour turnover.

Absence and labour turnover rates were calculated over a six month period for each organization. Information on sanctions and motivation was obtained by means of a structured questionnaire applied to all weekly paid employees. All four companies were involved in the manufacturing of clothing and the employees were mostly coloured females. All of the respondents were coloured females.

The information on both sets of indices of deviant industrial behaviour was processed separately for each department in each organization, as well as for each organization as a whole. $^{8}$

\section{Findings}

The findings of this study reflect only the patterns of behaviour and attitudes of weekly paid female employees in four factories and it would, therefore, be judicious not to generalize too extensively. The patterns and nature of labour turnover and absenteeism found in these four organizations do, however, compare favourably with the patterns and nature of the two phenomena established by other researchers.

\section{Absenteeism}

- Job category and absenteeism are inversely related. Employees in the high job categories were found to be absent less often than those in the lower categories.

- Absenteeism rates decrease from the beginning of the year to the end. Many new employees join the organization in the beginning of the year and experience adaptation problems. Rates tend to decline sharply after March as the employees 'settle' into the routine of work, and continue to decrease to the end of the year except for a small increase in rates during the winter months due to illness.

- Older employees tend to have higher absence rates than younger employees. It must be borne in mind, however, that the median age of the employees was only 23,97 years and that 'older' employees were mostly married women who may have been more affected than the younger employees by familial ties and their concomitant responsibilities. 
- Absenteeism is not a reliable indicator of organizational effectiveness, as it is rather a function of the nature of the labour force and of external organizational factors such as housing, socio-economic and political situations and transport.

- However, on the other hand, it follows from the findings that, as there is a definite relationship between the level of satisfaction in the work situation and absenteeism rates, organizational factors cannot be totally disregarded. Absenteeism and both dissatisfaction and level of motivation were found to be directly related. It was also ascertained that absence rates decrease as wage rates and attractiveness of work increase. Gouldner ${ }^{\theta}$ states that '. . . a high absentee rate may go together with high informal cohesion when absenteeism is a group value'. This proposition was verified in the sense that absenteeism was found to increase as relations between employees improved, but decreased as relations between employees and management improved. ${ }^{13}$

\section{Labour Turnover}

- The labour turnover pattern established in this study coincides with that revealed by other researchers. ${ }^{10}$ The high labour turnover established in the beginning of the year was probably a function of the induction crisis, a concept which refers to the high number of new entrants into the work force. 'A second period, called the period of "differential transit", follows, during which workers get to know life in the organization and come to a decision on their ability to adjust to it. The rapid decline in absence rates which follows on the period of the initial induction crisis is therefore halted and an increase in the turnover rates is registered'. ${ }^{7,}$ p. ${ }^{31}$ A secondary peak is reached at the end of this period after which a third period arises: turnover rates decline consistently towards the end of the year. The employees who have survived the first two periods start to exhibit the characteristics of a quasipermanent labour force.

- Labour turnover seems to be an extremely reliable indicator of labour force stability in view of the fact that it was found to relate very closely to rate of stability (that is, number of employees with more than one year of service expressed as a percentage of the total labour force), median length of employee service, and tendency to terminate (that is, average total length of service of all employees divided by the number of previous engagements).

- Labour turnover varies between different organizations and different departments within an organization, both of these phenomena appearing to be a function of size (in terms of the number of employees). Organizational and departmental size related directly with labour turnover rates, that is, the cohesion and closeness of people in smaller work groups apparently leads to a lower turnover rate.

- Internal organizational factors appeared to be the primary cause of high labour turnover rather than external factors, as was the case with absenteeism. A strong relationship was found to exist between satisfaction and labour turnover rates, that is the more dissatisfied workers are, the higher the turnover rates will tend to be and vice versa, and labour turnover will decrease as wages and attractiveness of work increase; finally, labour turnover will decrease as relations with management improve.

\section{Sanctions and Motivation}

It was found that intentional sanctions were reported more often by the employees than situational sanctions. This means that the employees reacted more to people-oriented management styles than to production-oriented management styles. In the comparison of the four organizations a perfect inverse relationship between situational and intentional sanctions was revealed. The implication of this finding is that as intentional sanctions (people-oriented management styles) receive greater emphasis, employees will become less responsive or less sensitive to situational sanctions (production-oriented management styles); the converse is also true.

The well-known theory of Herzberg was used to test the nature of motivation in the four organizations. The nature of the relationship between employees and employer was found to be both the most important satisfier (motivator factor) and dissatisfier (hygiene factor), as indicated in Table 1.

Table 1 Motivational factors among respondents

\begin{tabular}{lcc}
\hline & \multicolumn{2}{c}{ Rank order } \\
Factor & Satisfier & Dissatisfier \\
\hline Work itself & 2 & 3 \\
Recognition of success & 7 & 7 \\
Opportunity for promotion & - & 8 \\
Relationship with superiors & 1 & 1 \\
Relationship with equals & 3 & 6 \\
Organizational policy & 6 & 7 \\
Physical conditions & 5 & 4 \\
Wages & 4 & 5
\end{tabular}

Work itself appeared to be an important satisfier and dissatisfier. It must be noted that this is not so much a function of the intrinsic nature of the work itself, but rather a function of the fact that a productivity bonus is paid in all the organizations. An employee may then say that she likes to work hard because she then qualifies for the bonus. At the same time, however, the nature of line production results in low employee control over his work, and consequently influences the work tempo and, thus, the productivity bonus; this might be an important source of dissatisfaction.

Relationships with equals are an important satisfier while not being an important dissatisfier. The low rank order of factors such as recognition of success and opportunity reflects the realism of the employees with regard to the opportunity possibilities of non-white employees particularly coloured women in South African industries. It is in view of this fact that employees apparently react so strongly to relationships with superiors and the importance of intentional sanctions (people-oriented management style).

\section{Testing of the Hypotheses}

Hypothesis 1

The correlations between labour turnover and absenteeism rates were not statistically significant; a positive correlation was, however, established. These findings might be explained by the fact that these two behavioural phenomena are caused by different factors, turnover primarily by internal organizational factors and absenteeism primarily by external organizational factors. The hypothesis that labour turnover and absenteeism will coincide in terms of variations in incidence is thus rejected. Labour turnover and absenteeism do, however, coincide in terms of patterns of incidence. 


\section{Hypothesis 2}

No meaningful relationship exists between the application of people-oriented management styles and absenteeism, while a strong positive relationship was established between the application of people-oriented management styles (intentional sanctions) and labour turnover. This hypothesis was, consequently, also partly rejected.

\section{Hypothesis 3}

The general pattern and direction of relationships between motivational factors on the one hand, and absenteeism and labour turnover on the other, provide significant additional understanding. Deviant industrial behaviour tends to vary inversely with satisfaction in the work situation and directly with dissatisfaction. The same holds true with the relationship between deviant industrial behaviour and wages. Employee dissatisfaction tends to vary more inversely than directly with absenteeism and labour tumover than does employee satisfaction. The following relationships concerning motivation and deviant industrial behaviour on the part of respondents in this study were also revealed:

- High absence and turnover rates will occur as workers react more to hygiene factors (dissatisfiers); the converse also holds true.

- Absenteeism and labour turnover will decrease as wages and attractiveness of work itself increase.

- Absenteeism and especially labour turnover will decrease as relationships between labour and management improve, and will increase as relationships among employees improve.

\section{Implications of the Research}

The fact that absenteeism is more a function of external organizational factors than, as is the case with labour turnover, of internal organizational factors, accentuates the importance of viewing employees as more than mere industrial units. Industrial behaviour can only be explained and understood if both internal and external factors are taken into account. Tolstoy once stated that 'The highest wisdom has but one science - the science of the whole - the science explaining the whole creation and man's place in it.' Labour turnover was established as a valid indicator of organizational effectiveness and/or of the well-being of the employee in the work situation, while absenteeism is a useful indicator of the overall well-being of the employee.

The finding that deviant industrial behaviour will increase as inter-employee relationships improve and decrease as employer-employee relationships improve holds farreaching implications for industrial politics. It can be said that strong informal systems of relationships will be formed more readily in a climate of poor employer-employee relationships, and that healthy employee-employer relationships will to a certain extent detract from the need for informal and formal employee pressure groups such as workers' unions. People usually only become politically aware under circumstances of deprivation.

Employees perceive people-oriented management styles as a very important determinator of their overall well-being. Physical motivators such as wages and the work environment do not motivate female coloured employees to the same extent as does the attitude of the management to the employees. A greater level of concentration on intentional sanctions or people-oriented management styles may prove to be cheaper in terms of financial and socio-psychological considerations than use of physical motivators. The gap between the technical organization, which involves the instrumental activities of the employees, and the social organization, which involves the expressive activities of the employees, arises out of the nature of the organization and is the cause of most industrial relations problems. This conflict is natural, but can nevertheless be reduced. The application of intentional sanctions is not necessarily limited to the informal system of relationships, but could fruitfully be applied to the formal system of relationships.

Managers should strive to eradicate the rigid boundary between the formal and informal systems of relationships, and thus, by implication, to integrate expressive activities with instrumental activities.

Motivation strategies should not be one-dimensional. The sentiment that low job category employees are mainly motivated by money seems to be a myth. The low job category employee will certainly respond positively to a wage increase or productivity bonus, but will perhaps respond even more favourably to a more people-oriented management style. Behind the employee's attitude towards the employer is not one simple impulse or value (money for example), but a complex combination of assessments of the objective reality of the organization and external environment on the one hand, and values, attitudes and beliefs drawn from different levels of his experience on the other.

Absenteeism and labour turnover rates are, in conclusion, very useful tools to the manager in assessing not only the well-being of his employees both inside and outside the organization, but also the effectiveness of his organization which after all is also partly dependent on the well-bcing of the employee.

\section{References}

1 MACMLLAN, I. C. 1975. Organization Dynamics, Study Guide 3, School of Business Leadership, University of South Africa, UNISA Publications, Pretoria, p. 6.

2 McDONOUGH, JOHN J. 1975. One day in the life of Ivan Denisovich: A study of the structural requisites of organization. Human Relations 28(4): 297.

3 ETZIONI, AMITAI, 1964. Modern organizations. Prentice-Hail, Englewood Cliffs, New Jersey, pp. 61-62.

4 International Encyclopaedia of the Human Sciences 14: 5.

5 PARSONS, TALCOTT, 1969. Politics and social structure. The Free Press, New York, p. 363.

6 RUSHING, WILliaM A. (ed.) 1967. Deviant Behaviour and Social Process. Rand McNally and Co., Chicago, p. 4.

7 CILLIERS, S. P. 1977. Absenteeism in Cape Industries - A summary report. University of Stellenbosch, p. 27, 28.

8 HUMAN, P. G. 1977. Die Arbeidsbestel in Kaapse Nywerheidsondernemings - 'n Vergelykende studie met spesiale verwysing na Arbeidsomset en Werksafwesigheid. Unpubl. M.A. Thesis, University of Stellenbosch, filed with Human Sciences Research Council, Pretoria.

9 GOULDNER, ALVIN W. 1954. Pattems of industrial bureaucracy. The Free Press, Glencoe, Illinois, p. 151.

10 RICE, A. K. et al, 1975. An examination of the boundaries of part institutions. Human Relations 4(4). 